\section{Comparison of Variability among Irradiated and Control Inbred Maize Lines via Morphological Descriptions and Some Quantitative Features}

\author{
Pál Pepó - Zoltán Bódi \\ University of Debrecen, Centre for Agricultural Sciences, \\ Faculty of Agricultural Sciences, \\ Department of Genetics and Plant Breeding, Debrecen \\ pepopal@agr.unideb.hu
}

\section{SUMMARY}

Knowledge of genetic diversity in breeding material is fundamental for hybrid selection programs and for germplasm preservation as well. Research has been done with nine irradiated (fast neutron) and four non-treated inbred lines. The aims of this study were (1) to investigate the degree of genetic variability detected with morphological description (based on CPVO TP/2/2) in these materials, (2) to compare the genetic changes among irradiated and non-irradiated maize inbred lines (based on some quantitative features). The irradiation did not change any of the characteristics clearly in positive or negative way, which can be related to the fact that the effect of induced mutation on genetic structure cannot be controlled. From the irradiated lines we have managed to select plants with earlier ripening times and better phenotypes. We could distinguish 3 main groups by the morphological features; these results match our expectations based on pedigree data. Markers distinguishable on the phenotypic level (e.g. antocyanin colouration, length of tassels) were significant in all lines.

Keywords: fast neutron irradiation, genetic variability, maize (Zea mays L.), morphological description, quantitative features

\section{INTRODUCTION}

Application of induced mutation in plant breeding began more than seventy years ago. Presently, there are 2252 officially recognized mutant strains generated by physical or chemical mutagenesis; more than half of which were produced during the last 20 years and likely many more strains exist bearing mutated genes built in by crosses (Maluszynski et al., 2000).

In sophisticated plant production, the most essential factors are variety, its genetic productivity, quality and yield stability. Different morphological mutants offer good possibilities for the production of modern hybrid combinations (Pepó and Pepó, 1993). The specific effects of the different radiation sources have to be investigated in detail as to their economically beneficial characteristics (Bálint, 1960). The mutant genes often build into a new strain not directly but by crosses (Szilágyi, 1978 cit. Bálint, 1996).

The recurrent selection achieved with inbred lines produced by mutational breeding can be combined with in vitro tissue culture and haploid techniques. In addition good quality combinations can be generated (Pepó, 2004; Pepó et al., 2004). Genetic variability as the base of all kinds of plant breeding - is desired in maize breeding too. The determination of similarity among lines of different origin is also cannot be neglected (Rady and Nagy, 1996). Hajósné et al. (1996) studied the genetic variability in the case of maize lines produced by colchicine treatment and chronic gamma irradiation and found significant differences between the economically important phenomena of different lines.

In Sutka and Bálint's studies (1971) different quantitative characteristics responded differentially to mutagen treatments. The ear heights and the number of lateral branches were more variable. The number of grain rows is determined genetically and between certain limits can be considered as strain markers (Menyhért, 1979). In the UPOV TG $2 / 6$ description of plant height it is also classified into the group of genetically complex, environmentally stable phenomena (Zsubori et al., 2002). Allen et al. and McKee et al. (cit. Zsubori et al., 2002) showed that the number of leaves and yield significantly correlated with the height of the plant.

The economically important features show complex mode of inheritance. Several authors published data on particular type of inheritance and values of heredity related to plant height, grain yield, etc. (Bálint, 1966; Herczegh, 1970; Schön et al., 1993). LAI (leaf area index), the size of assimilating surface, is one of the most important morphological markers (Berzsenyi, 2000). With the help of strain descriptions resulting from DUS studies it becomes possible to determine the most similar strains and to investigate similarity groups (Veress and Matók, 1999).

In this study we have examined the genetic variability among 9 irradiated and 4 original inbred maize lines. The detection of genetic variability has been done by morphological description (following the CPVO TP/2/2 guidelines) in the phenotypic level, supplementing with the data of the most important quantitative features of the lines. Our aim was to study the genetic variability resulted by the effect of irradiation and comparing these data to those of the control lines. Knowing the genetic diversity of these lines we can exploit their genetic potential (selecting parental lines, reducing the number of crosses) in our future hybrid breeding program.

\section{MATERIALS AND METHODS}

Plant material: 4 original and 9 irradiated inbred maize lines (Table 1). For the description of the irradiation treatment see Maráz et al. (1993) and Pepó and Tóth (2004). After 12 years of inbreeding a line can be considered as homozygote. Their selection can be done by their good combining and pollen producing abilities, strength of stalks. 
Origin of the tested lines

\begin{tabular}{|c|c|c|c|}
\hline Inbred lines & Origin & Type of irradiation & Dose (Gray) \\
\hline GK Mo 17 [control] & Cereal Research Non-Profit Company, Szeged & - & - \\
\hline UD 507 & GK Mo 17 & Fast neutron & 5 \\
\hline UD 355 & GK Mo 17 & Fast neutron & 5 \\
\hline GK F2 [control] & Cereal Research Non-Profit Company, Szeged & - & - \\
\hline UD 105 & GK F2 & Fast neutron & 10 \\
\hline UD 201 & GK F2 & Fast neutron & - \\
\hline GK 13 [control] & Cereal Research Non-Profit Company, Szeged & - & 5 \\
\hline UD 123 & GK 13 & Fast neutron & 15 \\
\hline UD 433 & GK 13 & Fast neutron & - \\
\hline GK 41 [control] & Cereal Research Non-Profit Company, Szeged & - & 10 \\
\hline UD 70 & GK 41 & Fast neutron & 5 \\
\hline UD 126 & GK 41 & Fast neutron & 20 \\
\hline UD 267 & GK 41 & Fast neutron & \\
\hline
\end{tabular}

Morphological description: lines were sown in two areas in randomized block design in biennial, small plot experiments, in 4 replications. The measured characteristics were determined by the average of 15 plants/plot following the CPVO TP/2/2 guidelines (using 25 features) and other quantitative characteristics. For the calculation of leaf area we have used Montgomery's formula (cit. Anda and Tóbiás, 1999). Data were evaluated by one-way variance analysis.

\section{RESULTS}

\section{Variability of quantitative features}

Data of plant height were taken up 1 week after flowering. Heights were reduced by the effect of irradiation in almost all cases (Table 2). The only exception was UD 105 line, which significantly overgrew the starting control line. Stalk diameter, an important marker of stalk strength, showed both negative and positive alterations comparing to the original line. The ear height was the feature that changed in the highest degree. The height did not influence the position of the upper ear. There was about a $20 \mathrm{~cm}$ difference in height between the original GK 13 and UD 433 lines. In these cases there were no striking differences between the control and treated lines, significant changes took place in both positive and negative ways. The number of leaves/plant showed significant negative changes only in the cases of GK 41 and its irradiated lines, except UD 126. Leaf area index was significantly increased in the cases of UD 105 (compared to GK F2) and $U D 126$ (compared to GK 41). A possible explanation can be found in the notable raise of the interval to mid-silking - higher with minimum of one FAO maturity group -, which results in the rise of their vegetation period. The time of mid-silking from planting showed significant decrease in each groups compared to line GK Mo 17, while significant increase was observed in the case of other groups. The more than two-week shift of flowering of line UD 267 compared to the control is conspicuous. Possibly the high irradiation dose - 20 Gy - triggered such alteration.

Variability of some quantitative features in irradiated and control maize lines (Debrecen, 2005)

\begin{tabular}{|c|c|c|c|c|c|c|c|}
\hline Lines & $\begin{array}{l}\text { Plant height } \\
\text { (cm) }\end{array}$ & $\begin{array}{l}\text { Diameter of } \\
\text { maize-stalk } \\
(\mathbf{m m})\end{array}$ & $\begin{array}{c}\text { Ear height } \\
\text { (cm) }\end{array}$ & $\begin{array}{c}\text { Number of } \\
\text { leaves per } \\
\text { plant }\end{array}$ & $\begin{array}{l}\text { Leaf area } \\
\text { index } \\
\left(\mathrm{m}^{2} / \mathrm{m}^{2}\right)\end{array}$ & $\begin{array}{l}1000 \text { kernel } \\
\text { weight } \\
\text { (g) }\end{array}$ & $\begin{array}{c}\text { Number of } \\
\text { days from } \\
\text { planting to } \\
\text { mid-silking }\end{array}$ \\
\hline GK Mo 17 & 228.1 & 22.1 & 79 & 12 & 2.29 & 366.25 & - \\
\hline UD 507 & $138.4 * * *$ & $20.3^{+}$ & $55 * * *$ & $11^{+}$ & $2.07 *$ & $310 * * *$ & $-3 * *$ \\
\hline UD 355 & $132 * * *$ & $20^{+}$ & $40 * * *$ & $10^{+}$ & $1.45 * * *$ & $309.75 * * *$ & $-12 * * *$ \\
\hline GK F2 & 121.2 & 13.2 & 35 & 9 & 0.72 & 204 & - \\
\hline UD 105 & $186^{* * * *}$ & $16^{* *}$ & $72 * * *$ & $11^{+}$ & $3.1 * * *$ & $373 * * *$ & $+8 * * *$ \\
\hline UD 201 & 132.4* & $9.8^{* *}$ & $33.2 * * *$ & $8^{+}$ & $1.02 * *$ & $185.25^{* * *}$ & $+6 * * *$ \\
\hline GK 13 & 162.6 & $13.2^{+}$ & 33.4 & 11 & 1.64 & 350.75 & - \\
\hline UD 123 & $151.3 * * *$ & $14.4^{+}$ & $39.7 * *$ & $10^{+}$ & $1.67^{+}$ & $329.75 * * *$ & $+5^{*}$ \\
\hline UD 433 & $149.5 * * *$ & $13^{+}$ & $53.3 * * *$ & $9.5^{+}$ & $1.16^{* *}$ & $269.5 * * *$ & $+4 *$ \\
\hline GK 41 & 188.9 & 20.7 & 58.5 & 12 & 2.67 & 313 & - \\
\hline UD 70 & $154.7 * * *$ & $22.1^{+}$ & $48.2 * * *$ & $10,3 * *$ & $1.38 * * *$ & $281.75^{* * *}$ & $+9 * * *$ \\
\hline UD 126 & $175^{* * *}$ & $18^{+}$ & $51.2 * * *$ & $11.2^{+}$ & $1.71 * * *$ & $344.75^{* * *}$ & $+13 * * *$ \\
\hline UD 267 & $165.2 * * *$ & $17.1 * *$ & $42.7 * * *$ & $10 * *$ & $1.72 * * *$ & $310^{* *}$ & $+15 * * *$ \\
\hline
\end{tabular}

Values followed by ${ }^{*},{ }^{* *},{ }^{* * *}$ are significant at $0.1 ; 0.05 ; 0.001$ probability levels in comparison with control lines. Values followed by ${ }^{+}$are not significant. 


\section{Analysis of morphological features}

The dendrogram on Figure 1 has been created by 25 examined features following the guidelines of CPVO TP/2/2. Based on the similarities among inbred lines we could distinguish 3 major groups. Group 1: GK 41, UD 126, UD 267; GK F2, UD 105, UD 201. Group 2: UD 123, UD 433, UD 70. Group 3: GK Mo 17, UD 507, UD 355, GK 13.

Figure 1: Dendrogram obtained from cluster analysis based on the morphological descriptions

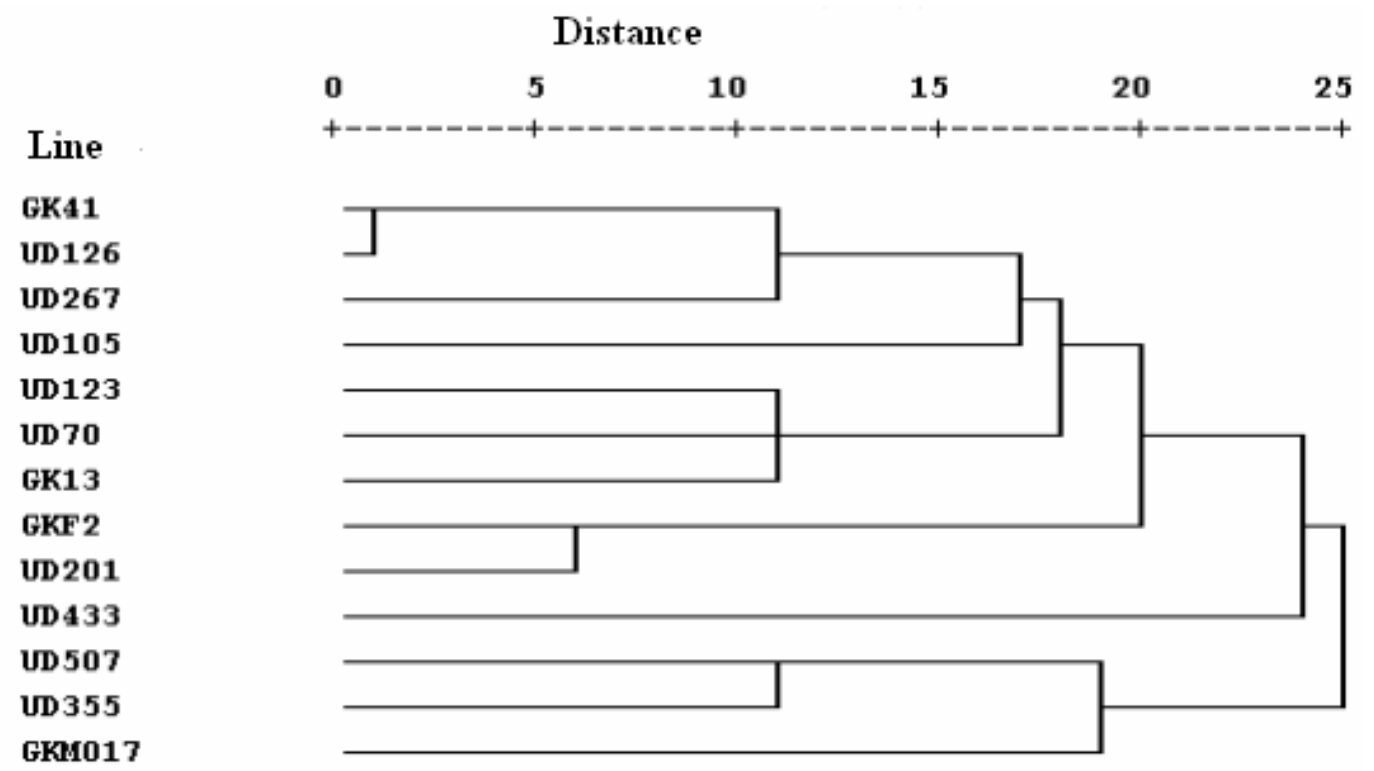

Based on the pedigree data in Group 1 GK F2 and its irradiated lines (UD 105 and UD 201) can be clearly separated from the others. Considering their kernel types these lines are not in close relationship with none of the other groups. Markers distinguishable on the phenotypic level (antocyanin colouration, length of tassels, etc.) were significant in all lines. The slightest morphological change was detected between GK 41 and UD 126.

\section{DISCUSSION}

To summarize our results we can conclude that the effects of phenomena possibly originated in the mutations caused by irradiation induced both positive and negative alterations in the plants.

Our results confirm the statement that the dose of irradiation can be different in all genotypes subject to the aim of experiment. According to the general hypothesis (Bálint, 1967) that low doses cause micro while high doses macro mutations is correct but the barriers of micro and macro mutations can be found at different levels in each genotypes. The most effective and cost-saving methods to increase genetic variability are still the application of physical mutagens. Their importance in maize breeding can increase in the next years since the world-wide spreading of genetically manipulated maize hybrids can narrow the genetic bases either in gene centre of maize or in other maize producing areas of the world.

\section{ACKNOWLEDGEMENTS}

The authors greatly appreciate the contribution of Cereal Research Non-Profit Company, Szeged for providing the control samples.

\section{REFERENCES}

Anda, A.-Tóbiás, F. (1999): Egyedi kukoricalevél területének meghatározására szolgáló eljárások és műszerek összehasonlító elemzése. Növénytermelés, 48. 1. 55-67.

Bálint, A. (1960): Sugárzásbiológiai módszerek alkalmazására növénynemesítésben. Növénytermelés, 9. 2. 181-190.

Bálint, A. (1966): Kukorica. In: Mezögazdasági növények nemesítése. Mezőgazda Kiadó, Budapest, 238.

Bálint, A. (1967): Heterózis és mutáció a kukoricában. Akadémiai Kiadó, Budapest, 103-162.

Bálint, A. (1996): A brief history of the theory, methodology and application of mutation research. Acta Agronomica Hung., 44. 1. 93-107.
Berzsenyi, Z. (2000): Növekedésanalízis a növénytermesztésben. Növénytermelés, 49. 4. 389-404.

Hajósné Novák, M.-Dallmann, G.-Nagy, H. A. (1996): A genetikai variabilitás vizsgálata W117 $\mathrm{S}_{18}$ tetraploid kukorica vonalakban. Növénytermelés, 45. 4. 325-335.

Herczegh, M. (1970): Importance of yield components in the phenotype. In: Some methodological achievements of the Hungarian hybrid maize breeding. Ed.: Kovács, I. Akadémiai Kiadó, Budapest, 229-236.

Maluszynski, M.-Nichterlein, K.-van Zanten, L.-Ahloowalia, B. S. (2000): Officially released mutant varieties - The FAO/IAEA database. Mutation Breeding, 12. 1-11. 
Maráz, A-né-Pepó, Pá.-Tóth, Sz. (1993): Kukoricavonalak és populációk variabilitásának növelése mutációs úton. Növénynemesítési Tudományos Napok, Budapest, 63.

Menyhért, Z. (1979): Kukoricáról a termelőknek. Mezőgazdasági Kiadó, Budapest, 33.

Pepó, Pá. (2004): Using new methods in conventional breeding of maize (Zea mays L.). Cereal Research Communications, 32. 4. 485-491.

Pepó, Pá.-Pepó, Pé. (1993): Biological background of sustainable maize (Zea mays L.) production. Landscape and Urban Planning, 27. 179-184.

Pepó, Pá.-Tóth, Sz. (2004): Kukoricagénbank előállítása mutációval. Növénytermelés, 53. 3. 253-262.

Pepó, Pá.-Tóth, Sz.-Oskolás, H. (2004): A kukorica (Zea mays L.) elemtartalmának változása a tenyészidő során. (Changes in the element contents of maize (Zea mays L.) during the vegetation period.) Növénytermelés, 53. 4. 317-327.
Rady, F.-Nagy, M. (1996): A genetikai azonosság és a genetikai különbözőség helyzete a hibridkukorica vetőmagtermesztésben. Növénytermelés, 45. 4. 399-408.

Schön, C. C.-Lee, M.-Melchinger, A. E.-Guthrie, W. D.Woodman, W. L. (1993): Mapping and characterization of quantitative trait loci affecting resistance against second generation European corn borer in maize with the aid of RFLP's. Heredity, 70. 648-659.

Sutka, J.-Bálint, A. (1971): Mutagének hatása a kukorica mennyiségi jellegeinek változékonyságára. Növénytermelés, 20. 2. 99-107.

Veress, Z.-Matók, Gy. (1999): Hasonlósági csoportok a DUSfajtaleírások alapján. Növénytermelés, 48. 1. 43-53.

Zsubori, Zs.-Gyenes-Hegyi, Zs.-Illés, O.-Pók, I.-Rácz, F.-Szőke, Cs. (2002): Inheritance of plant and ear height in maize (Zea mays L.). Journal of Agricultural Sciences, Acta Agraria Debreceniensis, 8. 1-5. 